\title{
Contrasting roles of donor and recipient TGFB1 and IFNG gene polymorphic variants in chronic kidney transplant rejection
}

\author{
Papéis contrastantes das variantes polimórficas dos genes TGFB1 e IFNG do doador e do \\ receptor na rejeição crônica de transplantados renais
}

Verônica Porto Carreiro de Vasconcellos Coelho ${ }^{1,2,3}$, Rafael Ioschpe ${ }^{1}$, Cristina Caldas ${ }^{1}$, Monica Spadafora-Ferreira ${ }^{1,4}$, João Americo Fonseca ${ }^{5}$, Maria Regina Alves Cardoso ${ }^{3,6}$, Selma Aliotti Palacios ${ }^{1}$, Jorge Kali1 ${ }^{1,2,3}$, Anna Carla Goldberg ${ }^{3,7}$

\begin{abstract}
Objective: To assess the long-term impact (minimum of 3 years follow-up) of polymorphisms in cytokine genes in donor:recipient pairs on the results of the transplant. Methods: We compared genetic cytokine polymorphisms and the primary factors of risk for the development of chronic rejection in paired groups of renal transplant patients with and without chronic allograft nephropathy [CAN]. Results: Multivariate analysis indicated that the presence of the highproduction TT genotype (codon 10) of the transforming growth factor beta-1 (TGFB1) was protective in receptors $(p=0.017)$, contrasting with the increased risk when present in donor samples $(p=0.049)$. On the other hand, in the case of the gamma interferon studied, the greater frequency of the high production allele was protective in the analysis of the donor group $(p=0.013)$, increasing the risk of chronic nephropathy of the allograft when present in the recipients $(p=0.036)$. Conclusion: Our results highlight the importance of TGFB1 genotyping in donors, and indicate that polymorphisms in the gene of this cytokine in donor cells might contribute to the development of chronic allograft nephropathy
\end{abstract}

Keywords: Chronic renal allograft dysfunction; Genetic polymorphism; Donor genotype; Transforming growth factor beta-1; Interferon-gamma

\section{RESUMO}

Objetivo: Avaliar o impacto de longo prazo (com seguimento mínimo de 2 anos) de polimorfismos em genes de citocinas em pares doador:receptor sobre os resultados do transplante. Métodos: Comparamos os polimorfismos genéticos das citocinas e os principais fatores de risco para o desenvolvimento de rejeição crônica em grupos pareados de pacientes transplantados renais com e sem nefropatia crônica do aloenxerto [CAN]. Resultados: A análise multivariada indicou que a presença do genótipo $\Pi T$ (códon 10) de alta produção do fator de crescimento transformador beta-1 (TGFB1) era protetor nos receptores $(p=0,017)$, em contraste com o risco aumentado quando presente nas amostras de doadores $(p=0,049)$. Por outro lado, no caso do interferon gama estudado, a maior frequência do alelo de alta produção foi protetora na análise do grupo de doadores $(p=0,013)$, mas aumentava o risco de nefropatia crônica do aloenxerto quando presente nos receptores $(p=0,036)$. Conclusão: Nossos resultados ressaltam a importância da genotipagem de TGFB1 também em doadores, e indicam que polimorfismos no gene desta citocina em células do doador podem contribuir no desenvolvimento da nefropatia crônica do aloenxerto.

Descritores: Disfunção renal crônica do aloenxerto; Polimorfismo genético; Genótipo do doador; Fator transformador de crescimento-beta 1; Interferon gama

\section{INTRODUCTION}

In spite of accumulated knowledge, the reasons why some patients, but not others, with similar clinical backgrounds, develop chronic rejection after renal transplantation are still unclear. The inflammatory nature of rejection has led to the query on the

\footnotetext{
Study carried out at Instituto do Coração, Faculdade de Medicina, Universidade de São Paulo, - USP - São Paulo (SP), Brazil

${ }^{1}$ Instituto do Coração, Faculdade de Medicina, Universidade de São Paulo - USP - São Paulo (SP), Brazil

${ }^{2}$ Divisão de Imunologia Clínica e Alergia, Faculdade de Medicina, Universidade de São Paulo, - USP - São Paulo (SP), Brazil

${ }^{3}$ Instituto de Investigação em Imunologia - Institutos Nacionais de Ciência e Tecnologia, Brazil

${ }^{4}$ Laboratório de Imunogenética, Instituto Butantan, São Paulo, Brazil

${ }^{5}$ Unidade de Transplante Renal, Faculdade de Medicina, Universidade de São Paulo - USP - São Paulo (SP), Brazil

${ }^{6}$ Departamento de Epidemiologia, Faculdade de Saúde Pública, Universidade de São Paulo - USP - São Paulo (SP), Brazil

7 Instituto Israelita de Ensino e Pesquisa Albert Einstein - IIEPAE - São Paulo (SP), Brazil

Autor correspondente: Anna Carla Goldberg - Av. Albert Einstein 627, 2SS, Bloco A - Morumbi - CEP 05652-000 - São Paulo (SP), Brasil. - Tel.: 2151-0941 - e-mail: goldberg@einstein.br

Received: Aug 16, 2010 - Accepted: Jan 24, 2011

* Conflicts of interest? none
} 
contribution of cytokine gene polymorphisms to the outcome of solid organ grafting, especially in the case of kidneys. Initial studies starting over 10 years ago, in renal transplanted patients, highlighted an association between the high production -308 TNFA allele and a low production $I L 10$ genotype with acute rejection ${ }^{(1,2)}$ and polymorphic IFNG CA repeat and ILIO genotype in chronic rejection ${ }^{(2)}$.

Chronic allograft nephropathy (CAN) is identified by a progressive decline in renal function, and presents with typical histological features. These include the hallmarks of inflammatory processes, such as mononuclear cell infiltration, perivascular and interstitial inflammation, fibrosis, hyperplasia of the intima leading to partial or total decrease of the vascular lumen, tubular atrophy, and even glomerulosclerosis and ischemia. After 10 years, over $50 \%$ of patients will have developed CAN (3) culminating with a loss of the graft itself. In spite of the ever-increasing improvement of immunosuppressive protocols, CAN still remains a major problem partly as a result of the use of calcineurin inhibitors. In addition, a variety of factors have been reported associated with the development and progression of CAN. Donor/recipient HLA (Human Leukocyte Antigen) disparity, the basis of alloreactivity and acute rejection, is a major risk factor; donor age, graft cold ischemia time, the number of acute rejection episodes, hyperlipoproteinemia, hypertension, and CMV infection episodes have also been established as factors in the progression of chronic allograft dysfunction (reviewed in detail in ${ }^{(4,5)}$.

In the initial phases of CAN, increased HLA expression and inflammatory cytokines such as IL-1 (Interleukin 1), IFN- $\gamma$ (Interferon gamma), and TNF- $\alpha$ (Tumor necrosis factor alpha), in addition to MCP-1 (Monocyte chemotactic protein 1) are present, as mononuclear cells infiltrate the kidney and adhere to the endothelium. At a later stage, concomitant to the proliferation of myofibroblasts and intimal hyperplasia, cytokines shift to a type 2 profile, which includes IL-4, IL-10, and TGF- $\beta 1$ (transforming growth factor beta 1 ), as well as PDGF (platelet-derived growth factor) and EGF (epidermal growth factor) ${ }^{(6)}$. This combination of factors is responsible for the phenotypic transformation of fibroblasts into myofibroblasts ${ }^{(7)}$. Endothelium and smooth muscle cells stain brightly for TNF- $\alpha$, PDGF, and TGF- $\beta 1^{(8)}$. TGF- $\beta 1$ is also expressed on fibroblasts and areas of fibrosis ${ }^{(9)}$. Though immunohistochemistry studies show that TGF- $\beta 1$ is present in biopsies from kidneys with either acute or chronic rejection, a clearly enhanced staining of the interstitium is observed in chronic rejection ${ }^{(10)}$. Finally, cyclosporine A, the major immunosuppressant drug used in renal transplanted patients, has been shown to induce TGF- $\beta 1$ production in a proximal tubular cell line ${ }^{(11)}$, and a similar effect has been described for tacrolimus ${ }^{(12)}$. On the other hand, TGF- $\beta 1$ has been repeatedly reported as a regulatory cytokine playing an important role in many models of tolerance, contributing to the immunosuppressive capacity of circulating CD4+CD25+ T lymphocytes in vivo ${ }^{(13)}$.

\section{OBJECTIVE}

In this study, we investigated genetic polymorphisms of some cytokine genes involved in the first steps and in the progression of atherosclerosis, in addition to known effector-phase and regulatory cytokines, aiming to identify susceptibility genes for CAN ${ }^{(14)}$. Polymorphisms of candidate cytokine genes were compared between groups of donor/recipient pairs with or without CAN, which were matched as best possible for major risk factors for CAN, such as level of HLA disparities, type and age of donor, number of acute rejection episodes, presence of hypertension, and cytomegalovirus (CMV) infection.

\section{METHODS}

\section{Subjects and follow-up}

This retrospective case:control study comparing two groups of patients, included patients who underwent renal transplantation and their respective donors at Hospital das Clínicas, University of São Paulo School of Medicine. The Ethics Committee approved this study and subjects gave their informed consent for blood sampling. Renal biopsies were performed according to clinical indications and classified according to Banff criteria ${ }^{(15)}$. DNA samples from 102 donor/recipient kidney transplant pairs were analyzed. Most patients received their transplant between 1995 and 2000. Of these, 56 recipients experienced biopsy-proven CAN and 46 were free of CAN with a minimum follow-up of 39 months. The two groups were comparable for major risk factors such as HLA compatibility (with two exceptions, all donor:recipient pairs were haploidentical or non-identical), level of previous sensitization, number of transfusions, and number of acute rejection episodes. Groups were also matched for progression factors such as donor type (living-related or unrelated) and age, presence of hypertension, hypercholesterolemia, and presence of anti-CMV IgG antibodies. The majority of patients were treated with conventional triple immunosuppressive therapy with cyclosporine, azathioprine, and prednisone. However, $68 \%$ of the patients were switched to MMF upon diagnosis of CAN, 
Table 1. Demographic and clinical features of the patients with and without chronic allograft nephropathy (CAN)

\begin{tabular}{|c|c|c|}
\hline Characteristics & Patients with CAN & Patients without CAN \\
\hline Pairs & 56 & 46 \\
\hline Gender $\mathrm{M} / \mathrm{F}$ & $26 / 30$ & $24 / 22$ \\
\hline Living donors $^{\mathrm{a}}$ & $39(69.6 \%)^{b}$ & $35(76.0 \%)$ \\
\hline Donor age ${ }^{c}$ & $38.37 \pm 12.05$ & $34.38 \pm 12.13$ \\
\hline Histocompatiblity -ID d & $3(5.4 \%)$ & 0 \\
\hline Histocompatiblity -HA ${ }^{d}$ & $25(44.6 \%)$ & $23(50.0 \%)$ \\
\hline Histocompatiblity $-\mathrm{NI}^{\mathrm{d}}$ & $28(50.0 \%)$ & $23(50.0 \%)$ \\
\hline Months of follow-up & $118.9 \pm 35.8$ & $94.4 \pm 31.0$ \\
\hline Acute rejection episodes (present) & $33(58.9 \%)$ & $20(43.5 \%)$ \\
\hline CMV positive post-transplant & 3 & 4 \\
\hline Hyperuricemia (present) ${ }^{\mathrm{e}}$ & $28(50.0 \%)$ & $20(30.0 \%)$ \\
\hline Graft loss due to CAN & $26(46.4 \%)$ & \\
\hline 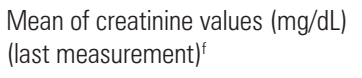 & $4.27\{1.1-22.0\}$ & $1.84\{0.6-7.8\}$ \\
\hline Pre-transplant transfusions $(n \geq 2)$ & $24(54,5 \%)$ & $26(61,9 \%)$ \\
\hline Dyslipidemia & $33(71.7 \%)$ & $20(54.1 \%)$ \\
\hline Hypertension & $40(81.6 \%)$ & $31(81.6 \%)$ \\
\hline $\mathrm{n}$ for multivariate analysis & 44 & 42 \\
\hline \multicolumn{3}{|c|}{$\begin{array}{l}\text { OObs: } 4 \text { (with CAN) and } 9 \text { (without CAN) living donors were unrelated (difference not significant) } \\
\text { "Values in parenthesis are percentage of total number of patients in the group } \\
\text { "Values are mean } \pm \text { standard deviation ( difference not significant by the Student } t \text { test for unpaired samples) } \\
\text { 'ID - HLA identical donor (sibling; } 0 / 6 \text { mismatches) } \\
\text { HA - haploidentical donor } 1-3 / 6 \text { mi'smatches } \\
\text { NI - nonidentical donor } 4-6 / 6 \text { mismatches } \\
\text { E Information not available in } 16 \text { CAN and } 6 \text { no CAN patients } \\
\text { 'Values in brackets correspond to the span of values found in the group }\end{array}$} \\
\hline
\end{tabular}

and some of the more recently transplanted patients received MMF from early on. Demographic features are shown in Table 1.

\section{DNA extraction and genotyping}

Blood samples were drawn and DNA extracted by DTAB/CTAB (Dodecyltrimethylammonium bromide/ Cetyltrimethylammonium bromide) ${ }^{(16)}$ or alternatively by salting-out methods (17) as described elsewhere. Unless otherwise mentioned, cytokine genotyping of 24 SNPs (single nucleotide polymorphisms) in 18 genes was performed by PCR-SSP (polymerase chain reaction with sequence-specific primers) on ready trays designed for the 13th International Histocompatibility Workshop on Cytokine Polymorphism by the Collaborative Transplant Study center in Heidelberg (http://www.ctstransplant. org/public/reagents.shtml). Briefly, PCR-SSP typing by the Heidelberg kit consisted of 48 PCR primer mixes dispensed in 96-well PCR trays. Master mix $(\mathrm{MgCl} 2$ buffer, dNTPs, and glycerol) was combined with $20 \mathrm{U}$ Taq polymerase and 1.2 - $3.0 \mu \mathrm{g}$ DNA, and dispensed onto the trays. Products were electrophoresed on $2 \%$ agarose gel and interpreted as defined by the Workshop protocol. The Heidelberg kit allowed SNP haplotyping for IL1B (-511 C/T and +3692 C/T), TGFB1 (codon 10 $\mathrm{C} / \mathrm{T}$ and $25 \mathrm{G} / \mathrm{C})$, TNFA (-238 G/A , and $-308 \mathrm{G} / \mathrm{A})$,
IL2 (-330 T/G and +160 G/T), IL4 (-1098 T/G, -590 C/T and $-33 \mathrm{C} / \mathrm{T})$, IL6 (-174 G/C, nt565 G/A), IL10 (-1082 $\mathrm{G} / \mathrm{A},-819 \mathrm{~T} / \mathrm{C}$ and $-590 \mathrm{~A} / \mathrm{C}$ ), and ICAM1 (G6241R and E465D) genes. The tray also permitted typing for single SNPs in genes coding for IFNG (3'UTR5644 A/T), IL1A (-889 C/T), IL1R (pst1970 C/T), IL1RN (mspa111100 C/T), IL12B (-1188 A/C), and IL4RA $(+1902 \mathrm{G} / \mathrm{A}) . M C P 1 \mathrm{SNP}$ at position $-2518(\mathrm{~A} / \mathrm{G})$ was analyzed by PCR-RFLP, using the following primers: forward CCGAGATGTTCCCAGCACAG and reverse CTGCTTTGCTTGTGCCTCTT ${ }^{(18)}$.

\section{Statistical analysis}

Bivariate analyses were carried out, using CAN as the dependent variable and the different gene polymorphisms investigated as independent variables. Variables significant in the bivariate analyses were the first entered into the multiple logistic regression models, but all other variables were tested. Two criteria were used to keep variables in the final model: statistical significance $(p<0.05)$ or a clear change in the estimates of the effects of some polymorphisms produced by those not selected in the first step of the analysis ${ }^{(19)}$. The analyses were performed using STATA software, version 8.0.

\section{RESULTS}

We analyzed 17 different gene polymorphisms, mostly cytokines associated with inflammation and/ or atherosclerosis, in both donor and recipient DNA samples. There was no deviation from expected HardyWeinberg proportions in any of the genes analyzed. Most SNPs analyzed, including those from ILIB (2 SNPs), IL4 (3 SNPs), IL10 (3 SNPs), ICAM1 (2 SNPs), and $M C P 1$, were equally distributed in groups with and without CAN, in donor and in recipient samples. Preliminary analyses led us to discard TNFA, IL2, IL6, and $I L 12 B$ as non-informative in our population due to their very low frequency in the healthy population, and were not tested further. A summary of the allele and haplotype frequencies in all groups is shown in Table 2.

In the case of $I L 1 A$ and $I L 1 B$, which are neighboring genes only about $60 \mathrm{~kb}$ apart, typing of $I L 1 A$ alleles in position -889 , and $I L 1 B$ SNPs at -511 and +3962 , disclosed at least 6 different haplotypes. However, in almost half of the cases, joint $I L 1 A / I L 1 B$ haplotypes could not be unambiguously defined. In other words, a comparison of ILIA/IL1B haplotype distribution in the two groups was not possible.

Of all genes analyzed, the sole significant difference disclosed upon Chi-square analysis was the presence of the high producer TT genotype in codon 10 of the 
Table 2. Summary of allele and haplotype frequencies in groups with and without chronic allograft nephropathy (CAN)

\begin{tabular}{|c|c|c|c|c|c|}
\hline \multicolumn{6}{|c|}{ Allele/Haplotype Frequency (\%) ${ }^{1}$} \\
\hline \multirow[b]{2}{*}{ Gene } & \multirow[b]{3}{*}{ Allele } & \multicolumn{2}{|l|}{ Recipient } & \multicolumn{2}{|l|}{ Donor } \\
\hline & & & & & \\
\hline SNP position & & No CAN & CAN & No CAN & CAN \\
\hline IL1A & C & 71.1 & 69.8 & 69.6 & 67.9 \\
\hline-889 & $\mathrm{~T}$ & 28.9 & 30.2 & 30.4 & 32.1 \\
\hline IL1B & C & 57.7 & 63.0 & 59.8 & 64.8 \\
\hline-511 & T & 42.3 & 37.0 & 40.2 & 35.2 \\
\hline IL1B & C & 80.0 & 80.5 & 84.8 & 83.0 \\
\hline 3962 & T & 20.0 & 19.5 & 15.2 & 17.0 \\
\hline IL1R & C & 63.3 & 57.4 & 58.7 & 57.5 \\
\hline Pstl 1970 & T & 36.7 & 42.6 & 41.3 & 42.5 \\
\hline ILIRA & C & 35.5 & 37.7 & 30.4 & 33.6 \\
\hline Mspa1 11100 & T & 64.5 & 62.3 & 69.6 & 66.4 \\
\hline IFNG & A & 58.9 & 59.8 & 60.0 & 63.2 \\
\hline UTR 5644 & T & 41.1 & 40.2 & 40.0 & 36.8 \\
\hline$I L 4^{*}$ & $\pi T$ & 36.0 & 32.1 & 39.1 & 29.8 \\
\hline \multirow[t]{4}{*}{$-1098 /-590 /-33$} & TCC & 51.2 & 58.0 & 52.2 & 55.8 \\
\hline & GTT & 1.2 & 1.2 & 1.1 & 4.8 \\
\hline & GCC & 11.6 & 4.9 & 7.6 & 7.7 \\
\hline & TTC & 0.0 & 3.8 & 0.0 & 1.9 \\
\hline IL10 & ACC & 30.2 & 36.7 & 34.8 & 39.6 \\
\hline \multirow[t]{2}{*}{$-1082 /-819 /-590$} & ATA & 37.7 & 27.7 & 33.7 & 26.4 \\
\hline & GCC & 32.1 & 35.6 & 31.5 & 34.0 \\
\hline MCP1 & $A$ & 73.0 & 72.0 & 67.4 & 73.6 \\
\hline-2518 & G & 27.0 & 28.0 & 32.6 & 26.4 \\
\hline ICAM1 & GG & 45.0 & 37.5 & 31.7 & 37.5 \\
\hline \multirow[t]{3}{*}{ G6241R/E465D } & $\mathrm{GA}$ & 48.3 & 53.6 & 56.7 & 53.6 \\
\hline & $A G$ & 5.0 & 8.9 & 11.6 & 8.9 \\
\hline & $\mathrm{AA}$ & 1.7 & 0.0 & 0.0 & 0.0 \\
\hline TGFB1** & $\mathrm{T}$ & 56.7 & 52.8 & 44.6 & 57.6 \\
\hline cdn10 & C & 43.3 & 47.2 & 55.4 & 42.5 \\
\hline TGFB1 & G & 96.6 & 92.5 & 93.5 & 91.5 \\
\hline $\operatorname{cdn} 25$ & C & 3.4 & 7.5 & 6.5 & 8.5 \\
\hline TGFB1 & CG & 38.9 & 39.6 & 48.9 & 34.0 \\
\hline \multirow[t]{2}{*}{ cdn10/cdn25 } & TG & 56.7 & 52.9 & 44.6 & 57.5 \\
\hline & CC & 4.4 & 7.5 & 6.5 & 8.5 \\
\hline
\end{tabular}

${ }^{1}$ According to the literature, alleles associated with high production are:

IL1A (-889*T), IL1B (-511*T; +3962*T), IL1RA (C), IFNG (T), TGFB1 (codon 10*T; codon 25*G), IL4 (-590*T: $\left.-33^{*} \mathrm{~T}\right)$, IL10 $\left(-1082^{*} \mathrm{G},-819^{*} \mathrm{C},-590^{*} \mathrm{C}\right), \mathrm{MCP} 1\left(-2518^{*} \mathrm{G}\right)$

UTR $=$ untranslated region : Pst1 and Mspa1 = restriction enzymes; $c d n=$ codon

* IL4, IL10, ICAM1 data are shown in the form of haplotypes

** TGFB1 data are shown as both allele and haplotype frequencies. TT Genotype (cdn 10) $\chi^{2}=6.547, p=0.0379$

TGFB1 gene $\left(\chi^{2}=6.547, \mathrm{p}=0.0379\right)$, present in almost $40 \%$ of transplant recipients with CAN, compared to $15 \%$ in the group free of CAN.

In the multivariate analysis, the IL1A low production allele was shown to be marginally protective when present in the graft $(\mathrm{p}=0.052)$. Results of the multivariate analysis can be seen in Table 3 . More importantly, the high production TGFB1 TT genotype (codon 10) was protective in recipients $(p=0.017)$ but conferred increased risk when present in donor samples $(\mathrm{p}=0.049)$. Conversely, in the case of IFNG polymorphism, the high production allele was protective in the donor analysis $(p=0.013)$, but increased the risk of CAN when present in recipients $(p=0.036)$. Finally, in spite of our careful matching of groups with and without CAN, and in accordance with published literature, acute rejection was confirmed as a risk factor for CAN $(\mathrm{p}=0.024)$. Hyperuricemia was analyzed in a smaller sample (67 instead of 86 pairs) and was also shown to be a risk factor for CAN $(\mathrm{p}=0.013$, C.I. 1.628-63.437, data not shown). On the other hand, donor type, donor age, number of HLA

Table 3. Multivariate analysis of gene polymorphisms significantly associated with CAN

\begin{tabular}{lcccc}
\hline Chronic rejection (CAN) & $\mathbf{O R}$ & $\mathbf{O R}_{\text {adj }}$ & $\mathbf{9 5 \%}_{\mathbf{a d j}}$ & $\mathbf{p - v a l u e}$ \\
\hline Acute cellular rejection & 1.87 & 4.12 & $1.20-14.13$ & 0.024 \\
TGFB codon 10 TT recipient genotype & 0.72 & 0.07 & $0.007-0.61$ & 0.017 \\
TGFB codon 10 TT donor genotype & 2.71 & 7.21 & $1.01-51.29$ & 0.049 \\
IFNG UTR5644 TT recipient genotype & 1.16 & 5.83 & $1.12-30.19$ & 0.036 \\
IFNG UTR5644 TT donor genotype & 0.72 & 0.16 & $0.04-0.68$ & 0.013 \\
\hline
\end{tabular}

ORadj = adjusted for HLA pairing, MCP1 at position -1025 recipient genotype, MCP-1 at position -1025 donor genotype, IL1B SNP at position -511 (T allele) recipient genotype, IL1B SNP at position -511 (C allele) donor genotype, IL1R (pstl 1970) recipient genotype, IL1R (pstl 1970) donor genotype, IL1B at position +3962 (C allele) recipient genotype and the other genotypes in this table.

disparities, presence of hypertension, dyslipidemia, number of pre-transplant transfusions, and months of follow-up, also included in the multivariate analysis, were equally distributed, and thus did not impact the result of the analysis.

\section{DISCUSSION}

Our case:control analysis of individual gene polymorphisms disclosed a significant increase of the $T G F B 1$ high production genotype in donors from the group with CAN. There was a trend toward significance in several other cytokine gene polymorphisms analyzed, however the relatively low number of patients in this study impacts upon this type of analysis. Thus, in order to counterbalance the lower power of the individual analysis we employed a multivariate analysis where all variables were taken into account. This analysis brought forth clear-cut results, confirming known risk factors like acute rejection episodes, as well as discriminating protective and risk-conferring cytokine gene polymorphisms. This was the case for TGFB1 and $I F N G$. Donor high production TGFB1 TT genotype (codon 10) was confirmed in a multivariate analysis to be associated with CAN, but the same genotype when present in the recipients conferred protection. In fact, despite TGF- $\beta 1^{\prime}$ s short-term tubule-repairing effect in the graft, its dominant intra-graft increased production seems to have an overall negative effect adding to progression of chronic rejection, enhancing 
myofibroblast proliferation and fibrosis. There is growing recognition of the importance of increased TGF- $\beta 1$ not only when CAN is already present, but also during acute rejection episodes and occurrence of cyclosporine nephrotoxicity, situations clearly associated with the development of CAN ${ }^{(20-22)}$. An enhancement of $T G F B 1$ transcription post-transplantation in the donor graft as a result of genetic polymorphism would partly explain these observations. This outcome contrasts with TGF- $\beta 1$ production by the recipients' $\mathrm{T}$ lymphocytes, where it is linked to suppression and down-regulation of inflammatory responses, as is largely reported in literature ${ }^{(23)}$. Accordingly, Park et al. ${ }^{(24)}$ found the frequency of TGFB1 lower and of intermediateproducing genotypes (codon $10 \mathrm{CC}$ and codon $25 \mathrm{GG}$ ) to be significantly higher in patients with recurrent acute rejection episodes, whereas high producer genotypes were increased in donors of patients with chronic renal allograft dysfunction. It is interesting to point out that this same high producer TGFB1 codon $10 \mathrm{~T}$ allele, when present in homozygosis in renal transplant recipients, was reported to be a potential risk for allograft function decline ${ }^{(25)}$. These heterogeneous data may, at least in part, reflect the effect of other relevant factors in CAN, including the positive or negative effect of other gene polymorphisms.

The presence of the TT genotype associated with a high production of IFN- $\gamma$ in the recipient group sample was identified as a risk factor in recipients, whereas when present in donor grafts it conferred protection. We do not have, at present, a good explanation for this last observation. IFN- $\gamma$ is produced almost exclusively by NKT, NK, and activated T lymphocytes, and thus the only source of donor IFN- $\gamma$ would be donor lymphocytes still present within the grafts at early time points after transplantation. Supporting a protective role for IFN- $\gamma$, a possible explanation has been put forth by Halloran et al. (26) in a study with recipient IFN- $\gamma$ knockout mice, where it was shown that IFN- $\gamma$ was essential to protect allografts locally from massive necrosis occurring upon grafting.

Probably due to the functional redundancy of immune responses, cytokine gene polymorphisms have repeatedly been shown to have a modest impact on overall disease susceptibility, acute rejection, and development of CAN, despite their significant roles in autoimmune and inflammatory conditions. Risks conferred by variant cytokine alleles rarely reach values of 2.5. The low impact of these polymorphic variants added to their low frequencies can render a study design underpowered to identify relevant targets with certainty. The relatively small number of donor/ recipient pairs, allied to the low genetic risk conferred by the cytokine polymorphisms we studied, requires that these results be confirmed. Matching groups for known variables when looking into multi-factorial susceptibility helps highlight hidden differences. Thus, our study groups were matched for donor type and age, HLA compatibility, presence of hypertension, dyslipidemia, number of pre-transplant transfusions, CMV positivity, and immunosuppressive regimen. Not unexpectedly, however, we were not able to control two well-known risk factors, namely the number of acute rejection episodes and hyperuricemia ${ }^{(27)}$, which were significantly increased in the CAN group.

However, the data we have obtained are generally in accordance with the published literature on the subject ${ }^{(28-30)}$.

\section{CONCLUSION}

Our results highlight the importance of donor cytokine genotyping and show that cytokine polymorphisms present in the grafted tissue might, indeed, contribute to the development of CAN. The combination of recipient and donor genotyping may help choose additional or alternative therapeutic approaches for renal transplant patients at higher risk, such as the early introduction of MMF or other drugs with a potential curbing effect on the development of CAN.

\section{ACKNOWLEDGMENTS:}

This work was supported by FAPESP (São Paulo State Research Foundation, grant \# 01/09850-0) and CNPq (National Council for Scientific and Technological Development, grant \# 0062/2001-0). ACG, MRAC, JK, and $\mathrm{VC}$ are recipients of personal grants from CNPq.

\section{REFERENCES}

1. Sankaran D, Asderakis A, Ashraf $S$, Roberts IS, Short CD, Dyer PA, et al. Cytokine gene polymorphisms predict acute graft rejection following renal transplantation. Kidney Int. 1999;56(1):281-8.

2. Asderakis A, Sankaran D, Dyer P, Johnson RW, Pravica V, Sinnott PJ, et al. Association of polymorphisms in the human interferon-gamma and interleukin10 gene with acute and chronic kidney transplant outcome: the cytokine effect on transplantation. Transplantation 2001;71(5):674-7.

3. Nankivell BJ, Borrows RJ, Fung CL, O'Connell PJ, Allen RD, Chapman JR. The natural history of chronic allograft nephropathy. N Engl J Med. 2003;349(24):2326-33.

4. Joosten SA, Sijpkens YW, van Kooten C, Paul LC. Chronic renal allograft rejection: pathophysiologic considerations. Kidney Int. 2005;68(1):1-13.

5. Li C, Yang CW. The pathogenesis and treatment of chronic allograft nephropathy. Nat Rev Nephrol. 2009;5(9):513-9.

6. Shirwan H. Chronic allograft rejection. Do the Th2 cells preferentially induced by indirect alloantigen recognition play a dominant role? Transplantation. 1999;68(6):715-26.

7. Desmouliere A, Geinoz A, Gabbiani F, Gabbiani G. Transforming growth factorbeta 1 induces alpha-smooth muscle actin expression in granulation tissue 
myofibroblasts and in quiescent and growing cultured fibroblasts. J Cell Biol.1993;122(1):103-11.

8. Noronha IL, Daniel V, Rambausek M, Waldherr R, Opelz G. Soluble interleukin-2 receptor (slL-2R) and tumor necrosis factor plasma levels in renal allograft recipients. Transplant Proc. 1990;22(4):1859-60.

9. Cuhaci B, Kumar MS, Bloom RD, Pratt B, Haussman G, Laskow DA, et al. Transforming growth factor-beta levels in human allograft chronic fibrosis correlate with rate of decline in renal function. Transplantation. 1999;68(6):785-90.

10. Shihab FS, Yamamoto T, Nast CC, Cohen AH, Noble NA, Gold LI, et al. Transforming growth factor-beta and matrix protein expression in acute and chronic rejection of human renal allografts. J Am Soc Nephrol. 1995;6(2): 286-94.

11. Wolf G, Zahner G, Ziyadeh FN, Stahl RA. Cyclosporin A induces transcription of transforming growth factor beta in a cultured murine proximal tubular cell line. Exp Nephrol. 1996;4(5):304-8.

12. Shihab FS, Bennett WM, Tanner AM, Andoh TF. Mechanism of fibrosis in experimental tacrolimus nephrotoxicity. Transplantation. 1997;64(12): 1829-37.

13. Chen W, Jin W, Hardegen N, Lei KJ, Li L, Marinos N, et al. Conversion of peripheral CD4+CD25- naive $T$ cells to $C D 4+C D 25+$ regulatory $T$ cells by TGF-beta induction of transcription factor Foxp3. J Exp Med. 2003;198(12): 1875-86.

14. Smith AJ, Humphries SE. Cytokine and cytokine receptor gene polymorphisms and their functionality. Cytokine Growth Factor Rev. 2009;20(1):43-59.

15. Racusen LC, Solez K, Colvin RB, Bonsib SM, Castro MC, Cavallo T, et al. The Banff 97 working classification of renal allograft pathology. Kidney Int. 1999;55(2):713-23.

16. Gustincich S, Manfioletti G, Del Sal G, Schneider C, Carninci P. A fast method for high-quality genomic DNA extraction from whole human blood. Biotechniques 1991;11(3):298-300- 2.

17. Bignon JD, Viña MF. HLA class II typing by PCR-SSOP. Charron D, Fauchet R, editors. Paris: EDK Medical and Scientific International Publisher; 1995.

18. Rovin BH, Lu L, Saxena R. A novel polymorphism in the MCP-1 gene regulatory region that influences MCP-1 expression. Biochem Biophys Res Commun. 1999;259(2):344-8.
19. Clayton D, Hills M. New York: Oxford University Press; 1996.

20. Sharma VK, Ding R, Li B, Bologa RM, Lagman M, Eduafo A, et al. Molecular correlates of human renal allograft rejection. Transplant Proc. 1998;30(5): 2364-6.

21. Pribylova-Hribova P, Kotsch K, Lodererova A, Viklicky O, Vitko S, Volk HD, et al. TGF-beta1 mRNA upregulation influences chronic renal allograft dysfunction. Kidney Int. 2006;69(10):1872-9.

22. Palomar R, Mayorga M, Ruiz JC, Cuevas J, Rodrigo E, Cotorruelo JG, et al. Markers of fibrosis in early biopsies of renal transplants. Transplant Proc. 2005;37(3):1468-70.

23. Huber S, Schramm C, Lehr HA, Mann A, Schmitt S, Becker C, et al. Cutting edge: TGF-beta signaling is required for the in vivo expansion and immunosuppressive capacity of regulatory CD4+CD25+ T cells. J Immunol. 2004;173(11):6526-31.

24. Park JY, Park MH, Park H, Ha J, Kim SJ, Ahn C. TNF-alpha and TGF-beta1 gene polymorphisms and renal allograft rejection in Koreans. Tissue Antigens. 2004 ; 64(6):660-6.

25. Chow KM, Szeto CC, Poon P, Lau WY, Lai FM, Li PK. Transforming growth factor-beta1 gene polymorphism in renal transplant recipients. Ren Fail. 2005;27(6):671-5.

26. Halloran PF, Miller LW, Urmson J, Ramassar V, Zhu LF, Kneteman NM, et al. IFN-gamma alters the pathology of graft rejection: protection from early necrosis. J Immunol. 2001;166(12):7072-81.

27. Perico N, Codreanu I, Caruso M, Remuzzi G. Hyperuricemia in kidney transplantation. Contrib Nephrol. 2005;147:124-31.

28. Hoffmann S, Park J, Jacobson LM, Muehrer RJ, Lorentzen D, Kleiner D, et al. Donor genomics influence graft events: the effect of donor polymorphisms on acute rejection and chronic allograft nephropathy. Kidney Int. 2004;66(4): 1686-93.

29. Hutchinson IV. The role of transforming growth factor-beta in transplant rejection. Transplant Proc. 1999;31(7A):9S-13S.

30. Awad MR, El-Gamel A, Hasleton P, Turner DM, Sinnott PJ, Hutchinson IV. Genotypic variation in the transforming growth factor-beta 1 gene: association with transforming growth factor-beta 1 production, fibrotic lung disease, and graft fibrosis after lung transplantation. Transplantation. 1998;66(8): 1014-20. 